\title{
Contextual Effect of Community Health Center on Patient Satisfaction of Health Care Service in Ngawi, East Java
}

\author{
Hendra Dwi Kurniawan'), Didik Tamtomo²), Bhisma Murti1) \\ 1)Masters Program in Public Health, Universitas Sebelas Maret \\ ${ }^{2)}$ Faculty of Medicine, Universitas Sebelas Maret
}

\begin{abstract}
Background: Perceived patient satisfaction is an important component of health care quality. This study aimed to determine the effect of age, education, income, health financing, quality of health care service, and the contextual effect of community health center on patient satisfaction.

Subjects and Method: This was a cross-sectional study conducted in 25 community health centers in Ngawi, East Java, from October to November 2018. A sample of 200 patients was selected by stratified random sampling. The dependent variable was patient satisfaction. The independent variables were age, education, income, health insurance, and quality of health care service. The data were collected by questionnaire and analyzed by a multilevel logistic regression.

Results: Age $\geq 35$ years ( $\mathrm{b}=0.99 ; 95 \% \mathrm{CI}=0.17$ to $1.81 ; \mathrm{p}<0.019$ ) and good quality of health care service $(b=1.68 ; 95 \% \mathrm{CI}=0.78$ to $2.59 ; \mathrm{p}<0.001)$ increased patient satisfaction. Education $\geq$ senior high school $(b=-1.59 ; 95 \% \mathrm{CI}=-2.49$ to $-0.68 ; \mathrm{p}<0.001)$, income $\geq \mathrm{Rp} 1,569,832(\mathrm{~b}=-1.32 ; 95 \% \mathrm{CI}=$ -2.25 to $-038 ; \mathrm{p}<0.006)$, and membership of national health insurance $(\mathrm{b}=-1.55 ; 95 \% \mathrm{CI}=-2.47$ too.63; $\mathrm{p}<\mathrm{0.001}$ ) decreased patient satisfaction. Community health center had contextual effect on patient satisfaction with ICC $=13.03 \%$.

Conclusion: Age $\geq 35$ years and good quality of health care service increase patient satisfaction. Education $\geq$ senior high school, high income, and membership in national health insurance decrease patient satisfaction. Community health center has contextual effect on patient satisfaction.
\end{abstract}

Keywords: patient satisfaction, community health center, multilevel analysis

\section{Correspondence:}

Hendra Dwi Kurniawan. Masters Program in Public Health, Universitas Sebelas Maret, Jl. Ir. Sutami 36 A, Surakarta 57126, Central Java. Email: hendradeeka@gmail.com

\section{BACKGROUND}

Primary health care has undergone several changes in the past few decades and system improvements to improve its service capacity to be more effective, qualified, similar and safe. In order to realize Universal Health Coverage in 2019, the government carries out a variety of strengthening health services at both first-level health facilities and reference levels (Naili, 2016).

Public Health Centers or Puskesmas are health service facilities that carry out public health efforts and first-rate individual health efforts, with more emphasis on promotive and preventive efforts, to achieve the highest degree of public health in their working area (Ministry of Health, 2014).

As health care providers, PHC must ensure that services are of high quality, efficient, acceptable and equal to consumers. A competitive environment and the patient's perception of the quality of health services are important factors when choosing a health center. Improving living standards must be balanced by providing standards higher than the quality of services to users of health services (Gunawan, 2011).

Efforts to improve the quality of service and patient safety in primary health care facilities, are through the implementa- 
Journal of Health Policy and Management (2019), 4(1): 23-30

https://doi.org/10.26911/thejhpm.2019.04.01.03

tion of quality improvement initiatives. One of them is through external assessment mechanisms such as accreditation (O'Beirne et al., 2013).

Ngawi Regency is one of the regencies in East Java Province which has 25 health centers, namely 5 health centers with the main accreditation status, 9 health centers with middle accreditation status, 4 health centers with major accreditation status, and 7 non-accredited health centers. Recognition is based on the results of external assessments that show the quality in providing health services and information in accordance with the needs and conditions of patients at the Puskesmas (District Health Office of Ngawi District, 2018).

Patient satisfaction is an important component to be taken into account in evaluating the quality and results of health services in developed and developing countries, including Indonesia. Patient satisfaction is achieved when the patient's perception of health services received has a positive, satisfying, and in accordance with what is expected (Joshi et al., 2013). Assessment of the level of patient satisfaction can have an impact on the development of the health system, increase the fulfillment of service needs, continuity of services, and ultimately will provide better health outcomes (Mohamed et al., 2015).

Patient satisfaction will establish trust in health facilities and will have a positive impact on patient behavior. Patient satisfaction is influenced by various factors, including the patient's socio-demographic status, type of payment used by the patient, and service quality (Risnandi et al., 2015; Kelarijani et al., 2014).

The importance of the level of patient satisfaction in achieving optimal health services needs to consider micro and macro levels, which take into account the factors of the health center. The purpose of this study is to analyze the effect of age, education level, patient income, type of financing, and service quality on patient satisfaction by taking into account the health center as a contextual factor.

\section{SUBJECTS AND METHOD \\ 1. Study Design \\ The was an analytic observational study with a cross-sectional design. The study was conducted in 25 community health centers in Ngawi, East Java, from October to November 2018.}

\section{Population and Sample}

The target population in this study were all outpatients at Ngawi community health centers. The source population was outpatients who visited Ngawi community health center. A sample of 200 out-patients was selected by stratified random sampling.

\section{Study Variables}

The dependent variable was patient satisfaction. The independent variables were age, education, income, type of health financing, and quality health service.

\section{Operational Definition of Variables}

Age was defined as length of time (year) from birth to the data collection. The measurement scale was continous and transformed into dichotomous, coded o for $<35$ years and 1 for $\geq 35$ years.

Education was defined as the highest formal education attained by study subjects. The measurement scale was categorical, coded o for $<$ senior high school and 1 for $\geq$ senior high school.

Patient income was defined as the amount of income each month the family receives in the form of honorarium, rent, including subsidies, or benefit. The measurement scale was continous and transformed into dichotomous, coded $\mathrm{o}$ for $<\mathrm{Rp}$ $1,569,832$ and 1 for $\geq \operatorname{Rp} 1,569,832$.

Health financing was defined as a method of paying off health care costs that 
have been obtained by patients. The measurement scale was categorical, coded o for not being member of national health insurance and 1 for membership in national health insurance.

Health quality service was defined as a measure of the extent to which a service can meet the needs of patients. Five dimensions of quality health service were responsiveness, reliability, assurance, empathy, and tangible. The measurement scale was continous and transformed into dichotomous, coded o for poor and 1 for good.

Patient satisfaction was defined as the patient's assessment that arises from the health services that are obtained after the patient compares it with what he expected. The measurement scale was continuous and transformed into dichotomous, coded o for low satisfaction and 1 for high satisfaction.

\section{Study Instruments}

The data were collected by questionnaire. The instrument reliability test was carried out on 20 patients who visited Ngawi community health centers. Reliability test was measured by total item correlation with $\mathrm{r}$ value $\geq 0.20$, and alpha Cronbach $\geq 0.60$. These results indicate that the questionnaire was reliable.

\section{Data Analysis}

Univariate analysis was done to determine sample characteristics by frequency and percentage. Bivariate analysis was carried out by Chi-square. Multivariate analysis was conducted by a multilevel logistic regression run on Stata 13.

\section{Research Ethics}

Research ethics of this study was obtained from Research Ethics Committee, Faculty of Medicine, Universitas Sebelas Maret, Surakarta, Central Java, Indonesia with numbers: 311/UN27.6/KEPK/2018.

\section{RESULTS}

\section{Sample characteristics}

Table 1 showed sample characteristics. Table 1 explained that as many as 109 outpatients (54.5\%) were at age $\geq 35$ years old. As many as 134 out-patients (67.0\%) had education level <senior high school. As many as 116 out-patients (58.0\%) had income $\geq \operatorname{Rp} 1,569,832$.

\begin{tabular}{lcc}
\multicolumn{3}{l}{ Table 1. Sample characteristics } \\
\hline Characteristics & $\mathbf{n}$ & $\mathbf{\%}$ \\
\hline Age & & \\
$\quad<35$ years & 91 & $45 \cdot 5$ \\
$\quad \geq 35$ years & 109 & 54.5 \\
$\quad$ Education Level & & \\
$\quad<$ senior high school & 134 & 67.0 \\
$\quad \geq$ senior high school & 66 & 33.0 \\
$\quad$ Income & & \\
$\quad<$ Rp 1,569,832 & 84 & 42.0 \\
$\quad \geq \operatorname{Rp~1,569,832}$ & 116 & 58.0 \\
\hline
\end{tabular}

\section{Bivariate Analysis}

Table 2 showed the results of bivariate analysis. Table 2 showed that age $\geq 35$ years $(\mathrm{OR}=3.67 ; 95 \% \mathrm{CI}=2.04$ to $6.62 ; \mathrm{p}$ $<0.001)$ and good health service quality $(\mathrm{OR}=3.41 ; 95 \% \mathrm{CI}=1.86$ to $6.23 ; \mathrm{p}$ $<0.001)$ increased patient satisfaction.

Education $\geq$ senior high school (OR= 0.09; $95 \% \mathrm{CI}=0.47$ to $0.19 ; \mathrm{p}<0.001)$, high income $(\mathrm{OR}=0.014 ; 95 \% \mathrm{CI}, 0.07$ to 0.28 ; $\mathrm{p}<0.001)$ and membership in health insurance $(\mathrm{OR}=0.11 ; 95 \% \mathrm{CI}, 0.05$ to 0.22 ; $\mathrm{p}<0.001)$ decrease patient satisfaction.

\section{Multilevel Analysis}

Table 3 showed the results of multilevel analysis. Table 3 showed that patients aged $\geq 35$ years old had a logodd of satisfaction on health service 0.99 unit higher than aged $<35$ years old $(b=0.99 ; 95 \% \mathrm{CI}=0.17$ to $1.81 ; \mathrm{p}<0.019)$. There was a relationship between educational level and patients' satisfaction. 
Journal of Health Policy and Management (2019), 4(1): 23-30

https://doi.org/10.26911/thejhpm.2019.04.01.03

Table 2. The Result of Bivariate Analysis of Factors that Affect Patients' Satisfaction by Using Chi-Square

\begin{tabular}{|c|c|c|c|c|c|c|c|c|c|c|}
\hline \multirow{3}{*}{ Variables Group } & \multicolumn{4}{|c|}{ Patients Satisfaction } & \multirow{2}{*}{\multicolumn{2}{|c|}{ Total }} & \multirow{3}{*}{$\mathbf{O R}$} & \multicolumn{2}{|c|}{ CI (95\%) } & \multirow{3}{*}{$\mathbf{p}$} \\
\hline & \multicolumn{2}{|c|}{ Low } & \multicolumn{2}{|c|}{ High } & & & & Lower & Upper & \\
\hline & $\mathbf{n}$ & $\%$ & $\mathbf{n}$ & $\%$ & $\mathbf{n}$ & $\%$ & & Limit & Limit & \\
\hline \multicolumn{11}{|l|}{$\overline{\text { Age }}$} \\
\hline$<35$ years old & 55 & 39.6 & 36 & 51.4 & 91 & 100.0 & 3.67 & 2.04 & 6.62 & $<0.001$ \\
\hline$\geq 35$ years old & 32 & 47.4 & 77 & 61.6 & 109 & 100.0 & & & & \\
\hline \multicolumn{11}{|l|}{ Educational Level } \\
\hline$<\mathrm{HS}$ & 35 & 26.1 & 99 & 73.9 & 134 & 100.0 & 0.09 & 0.47 & 0.19 & $<0.001$ \\
\hline$\geq \mathrm{HS}$ & 52 & 78.8 & 14 & 21.2 & 66 & 100.0 & & & & \\
\hline \multicolumn{11}{|l|}{ Income } \\
\hline <Rp. 1.569.832,- & 16 & 19.0 & 68 & 81.0 & 84 & 100.0 & 0.014 & 0.07 & 0.28 & $<0.001$ \\
\hline >Rp. $1.569 .832,-$ & 71 & 61.2 & 45 & 38.8 & 116 & 100.0 & & & & \\
\hline \multicolumn{11}{|l|}{ Type of Financing } \\
\hline Regular & 15 & 17.0 & 73 & 83.0 & 88 & 100.0 & 0.11 & 0.05 & 0.22 & $<0.001$ \\
\hline HI & 72 & 64.3 & 40 & $35 \cdot 7$ & 112 & 100.0 & & & & \\
\hline \multicolumn{11}{|l|}{$\begin{array}{l}\text { The Quality of } \\
\text { Services }\end{array}$} \\
\hline Poor & 45 & 62.5 & 27 & 37.5 & 72 & 100.0 & 3.41 & 1.86 & 6.23 & $<0.001$ \\
\hline Good & 42 & 32.8 & 86 & 67.2 & 128 & 100.0 & & & & \\
\hline
\end{tabular}

Table 3. The results of multilevel analysis

\begin{tabular}{|c|c|c|c|c|}
\hline \multirow{2}{*}{ Independent Variables } & \multirow{2}{*}{$\mathbf{b}$} & \multicolumn{2}{|c|}{$95 \% \mathrm{CI}$} & \multirow{2}{*}{$\mathbf{p}$} \\
\hline & & Lower Limit & Upper Limit & \\
\hline \multicolumn{5}{|l|}{ Fixed Effect } \\
\hline Age $\geq 35$ years old & 0.99 & 0.17 & 1.81 & $<0.019$ \\
\hline Educational $\geq$ senior high school & -1.59 & -2.49 & -0.68 & $<0.001$ \\
\hline Income $\geq \operatorname{Rp} 1,569,832$ & -1.32 & -2.25 & -0.38 & $<0.006$ \\
\hline Membership in health insurance & -1.55 & -2.47 & -0.63 & $<0.001$ \\
\hline Good quality of health service & 1.68 & 0.78 & 2.59 & $<0.001$ \\
\hline \multicolumn{5}{|l|}{ Random Effect } \\
\hline Var (constant) & 0.49 & 0.06 & 3.67 & \\
\hline \multicolumn{5}{|c|}{$\begin{array}{l}\text { LR test vs. Logistic Regression: chibar2 }(01)=1.81 \\
p=0.089\end{array}$} \\
\hline Intraclass Correlation (ICC) & & $13.03 \%$ & & \\
\hline
\end{tabular}

Patients with education $\geq$ senior high school had a logodd of satisfaction 1.59 units lower than patient with <senior high school $(b=-1.59 ; 95 \% \mathrm{CI}=-2.49$ to -0.68 ; $\mathrm{p}<0.001)$. There was a relationship between income and patient satisfaction. Patient with income $\geq \operatorname{Rp~1,569,832~had~a~logodd~of~}$ satisfaction on health services by 1.32 lower than patient with income $<\mathrm{Rp} 1,569,832$ $(\mathrm{b}=-1.32 ; 95 \% \mathrm{CI}=-2.25$ to $-0.38 ; \mathrm{p}$ $<0.006)$. There was a relationship between health financing and patient satisfaction. Patients who had health insurance had a logodd of satisfaction on health service by 1.55 lower than patient without health financing $(b=-1.55 ; 95 \% \mathrm{CI}=-2.47$ to -0.63 ; 
$\mathrm{p}<$ 0.001). There was a relationship between quality service and patient satisfaction. Good quality health service increased logodd patients satisfaction by 1.68 higher than poor quality health service $(b=1.68$; $95 \% \mathrm{CI}=0.78$ to $2.59 ; \mathrm{p}<0.001)$.

Community health center had a contextual effect on patient satisfaction with $\mathrm{ICC}=13.03 \%$ ).

\section{$\frac{\text { DISCUSSION }}{\text { 1. The effect of age on patient satis- }}$ faction}

The result of this study showed that there was a significant relationship between age and patient's satisfaction. Patients aged $\geq 35$ years old were 0.99 time more likely to have high level of satisfaction than patients aged $<35$ years old.

The result of this study was supported by a study done by Olumodeji et al. (2015), which stated thatthere was a significant relationship between age and patient satisfaction. Patients aged 35 years old and over assumed that the service provider was able to provide quality services and fulfill patients' needs so that it influenced the high level of satisfaction.

A study done by Sanchez-Piedra et al. (2014) also stated that there was a significant relationship between age and patient's satisfaction. The older the age of the patient, the higher the satisfaction on health services. Patients who were older did not demand much and have lower expectations so they tend to feel satisfied with the services provided.

\section{The effect of education on patient satisfaction}

The result of this study showed that there was a significant effect of educational level on patient's satisfaction. Highly-educated patients have lower satisfaction compared to patients with low educational levels.
The result of this study was in line with a study done by Risnandi et al. (2015) and Mohamed et al (2015) which stated thatthere was a significant effect of educational level on patient's satisfaction. Patients with a high level of education would understand more about health and tend to have high expectations for health services. Unlike someone with a low level of education, she/he tend to be more receptive and satisfied with the services provided because they did not know what they needed.

A study done by Kelarijani et al (2014) also showed that highly-educated patients tend to have low satisfaction to health services. The level of satisfaction of people with higher education would decrease when they expectations were not fulfilled.

\section{The effect of income on patient satisfaction}

The result of this study showed that there was a significant effect of income on patient satisfaction. The higher income, the lower satisfaction of health service.

The result of this study was in line with a study done by Akbar et al. (2017) and Kelarijani et al. (2014) which stated thatpatients with high income tend to have low levels of satisfaction.

Income was one of the factors that influenced the perception. High income would affect expectations and greater demands on health services needed because of financial capacity. In contrary, people with low income tend to accept minimal health services without more demands and expectations (Mohamed et al, 2015). Therefore, income would eventually determine perceived satisfaction to the health services.

\section{The effect of type of financing on patient satisfaction}

The result of this study showed that there was a significant effect of type of financing on patient's satisfaction. Patients who use health insurance had a lower level of satis- 
faction compared to patients who use a type of general financing (fee for service).

A study of Budi (2010) and Utami et al. (2017) showed that differences in financing systems affected differences in the quality of health services that have an impact on the differences in patient's satisfaction. Patients with health insurance got poor quality of health services compared to non-health insurance patients (Imelda et al., 2015).

The result of this study was in line with a study by Shi et al. (2015) which stated that there was a meaningful difference between the use of health insurance and patient satisfaction. Patients who used regional health insurance have lower levels of satisfaction compared to regular patients who did not use health insurance.

\section{The effect of quality health service on patient satisfaction}

The result of this study showed that there was a significant effect of quality of services on patient satisfaction. The better the quality of health services received, the higher the level of patient satisfaction. Patients who got good quality of services have 5.37 times higher satisfaction compared to patients who got poor quality of services.

The result of this study was supported by a study by Andriani (2017) and Eninurkhayatun et al. (2017) which stated that there was a relationship between quality of health service and patient satisfaction. Good service quality affected the level of satisfaction. A study by Elleuch (2014) in Japan, also showed that the quality of health services affected the level of satisfaction in its aspects, namely technical and interpersonal aspects.

A study by Juwita et al. (2017) stated that there was a relationship between the quality of health services and patient satisfaction in all dimensions. The dimensions of the quality of health services consisting of tangible, reliability, responsiveness, assurance, and empathy which affected patient's satisfaction. Service quality was the proper value of the service unit, the better the patient's perception of the dimensions of service quality, the higher the level of patient's satisfaction (Al-damen, 2017).

\section{The effect of community health center on patient satisfaction}

The results of multilevel analysis showed that the score of ICC $=13.03 \%$, the indicator showed that variations in the characteristics of each health center have a contextual influence on variations of patient's satisfaction.

The result of this study was in line with a study by Adhikary et al. (2018) in Bangladesh which showed that there was a significant difference in the average level of patient satisfaction at each level of the health service agency. Health service institutions with good quality, including in terms of cleanliness of facilities, safeguarding the privacy, skills and attitudes of service providers, the timeliness of services affected high patients' satisfaction.

A study by Pullicino et al. (2016), in 70 primary health service providers in Malta explained that variations in primary health care providers affected the variations in patient health behavior, this showed the role of service quality in implementing standard operating procedures and service standards at each health service provider. Eventually, the quality of service affected patient's satisfaction $(\mathrm{ICC}=13 \%)$.

Another study that supported the results of this study was conducted by Mirshanti et al. (2017) and Widayati et al. (2017), which showed that the status of accreditation of health centers affected patient satisfaction. The higher the level of accreditation status of the health center, the better the quality of service, and ultimately 
it would increase patient's satisfaction. In this study, $72 \%$ of health centers were accredited with variations in their accreditation status, and $28 \%$ of health centers were not accredited. Health centers with quality services according to accreditation standards tend to increase patient satisfaction. Community Health Centers have their own characteristics in the scope of work area, potential resources, and quality of health services. These characteristics can affect patient's satisfaction with the service that they received (Goetz et al., 2015).

Based on the result of this study, it was necessary to optimize the monitoring of service quality on a regular basis, and improve the quality of service for each health service provider agency, as well as cross-sectoral cooperation to achieve optimal public health degrees.

\section{REFERENCES}

Akbar PS, Adriani RB, Murti B (2017). The influence of personal factors of the patient, doctor, payment method. and type of class to the quality and satisfaction of inpatient care services in Dr. Moewardi Hospital Surakarta. Journal of Health Policy and Management, 2(1): 1-15 .

Al-Damen R (2017). Health care service quality and its impact on patient satisfaction "case of Al-Bashir Hospital". International Journal of Business and Management, 12(9): 136-152.

Andriani A (2017). Hubungan mutu pelayanan kesehatan dengan kepuasan pasien di ruangan Poli Umum Puskesmas Bukittinggi. Journal Endurance, 2(1): 45-52.

Budi HS (2010). Hubungan antara sistem pembiayaan dengan kualitas pelayanan di puskesmas Slogohimo Wonogiri. Thesis. Surakarta: Universitas Sebelas Maret.
Dinas Kesehatan Kabupaten Ngawi (2018). Daftar Status Kelulusan Akreditasi Puskesmas Dinas Kesehatan Kabupaten Ngawi per Oktober 2018. Ngawi: Dinas Kesehatan Kabupaten Ngawi.

Elleuch A (2014). Patient satisfaction in Japan. International Journal of Health Care Quality Assurance, 21 (7): 692-705.

Eninurkhayatun B, Suryoputro A, Fatmasari EY (2017). Analisis Tingkat kepuasan pasien terhadap kualitas pelayanan rawat jalan di Puskesmas Duren dan Puskesmas Bergas Kabupaten Bergas. Jurnal Kesehatan Masyarakat, 5(4): 33-42.

Goetz K, Hess S, Jossen M, Huber F, Rosemann T, Brodowski M, Kunzi B, et al. (2015). Does a quality management system improve quality in primary care practices in Switzerland? A Longitudinal Study. BMJ Open, 5: 74-83.

Gunawan K (2011). Kualitas Layanan dan Loyalitas Pasien. Jurnal Manajemen dan Kewirausahaan, 1(1):32-39.

Imelda S, Nahrisah E (2015). Analisis tingkat mutu pelayanan rawat inap dalam upaya peningkatan kepuasan pasien di RSUP Adam Malik Medan (studi perbandingan antara pasien umum dan pasien BPJS). J. Infor-matika AMIK-LB, 3(3): 92-105.

Joshi K, Sochaliya K, Purani S, Kartha G (2013). Patient satisfaction about health care services: A cross sectional study of patients who visit the outpatient departement of a civil hospital at Surendranagar, Gujarat. International Journal of Medical Science and Public Health, 2(3): 659-663.

Juwita GS, Marlinae L, Rahman F (2017). Hubungan mutu pelayanan dengan kepuasan pasien rawat inap di Rumah Sakit Umum Daerah Tamiang Layang. 
Journal of Health Policy and Management (2019), 4(1): 23-30

https://doi.org/10.26911/thejhpm.2019.04.01.03

Jurnal Publikasi Kesehatan Masyarakat Indonesia, 4(2): 49-58.

Kelarijani SEJ, Jamshidi R, Heidarian AR, Khorshidi M (2014). Evaluation of factors influencing patient satisfaction in social security hospitals in Mazandaran province, North of Iran. Caspian J Intern Med, 5(4): 232-234.

Kemenkes RI (2014). Peraturan Menteri Kesehatan Republik Indonesia Nomor 75 tahun 2014 tentang Pusat Kesehatan Masyarakat. Jakarta: Kementerian Kesehatan Republik Indonesia.

Mirshanti F, Tamtomo D, Murti B (2017). The asssociations between accreditation status, patient socio-economic factors, insurance type, patient perceived quality of service, and satisfaction at community health center. Journal of Health Policy and Management, 2(1): 91-101.

Mohamed EY, Sami W, Alotaibi A, Alfarag A, Almutairi A, Alanzi F (2015). Patients' Satisfaction with Primary Health Care Centers' Services, Majmaah, Kingdom of Saudiof Saudi Arabia. International Journal of Health Sciences, 9(2): 163-170.

Naili (2016). Akreditasi Puskesmas, Pentingkah?. Diakses dari http://www.kompasiana.com/nailinsn/akreditasipuskemas-pentingkah/ pada tanggal 5 Agustus2018

O’Beirne M, Zwicker K, Sterling PD, Lait J, Robertson HL, Oelke ND (2013). The status of accreditaion in primary care. Quality in Primary Care, 2(1):23-31.

Olumodeji AAD, Oluwole E (2015). Influence of socio demographic variables on patient's satisfaction with quality of nursing care in teaching hospitals in northern Nigeria. International Journal of Medical and Health
Research, 1(3): 18-24.

Pullicino G, Sciortino P, Camilleri L, Dchafer W, Boerma W (2016). The Influence of patient characteristics on healthcare-seeking behavior: a multilevel analysis of 70 primary care practices in urban-suburban regions in Malta. Quality in Primary Care, 24 (3): 106-110.

Risnandi C, Bunga AL, Supardi S (2015). Faktor-faktor yang berhubungan dengan kepuasan pasien rawat jalan di Puskesmas Lingga, Kabupaten Kubu Raya. Thesis. Jakarta: STIK Sint Carolus

Sanchez-Piedra C, Prado-Galbarro FJ, Garcia-Perez S, Santamera AS ( 2014). Factors associated with patient satisfaction with primary care in Europe: results from the EUprimecare project. Quality in Primary Care, 22:147-55.

Shi L, Lee D, Liang H, Zhang L, Makinen M, Blanchet N, Kidane R et al. (2015). Community health centers and primary care access and quality for chronically-ill patients - a case-comparison study of urban Guangdong Province, China.International Journal for Equity in Health. 14: 90-107.

Utami YT, Tomtomo D, Sulaeman ES (2017). Patient characteristics, financing type, accreditation status, and quality of health services at community. Journal of Health Policy and Management, 2(1): 79-90.

Widayati MY, Tamtomo D, Adriani RB (2017). Factors affecting quality of health service and patient satisfaction in community health centers in North Lampung, Sumatera Journal of Health Policy and Management, 2(2): 165-175. 